P-ISSN: 2774-4574; E-ISSN: 2774-4582 TRILOGI, 1(2), Sept - Des 2020 (72-82) @2020 Lembaga Penerbitan, Penelitian, dan Pengabdian kepada Masyarakat (LP3M) Universitas Nurul Jadid Paiton Probolinggo DOI: https://doi.org/

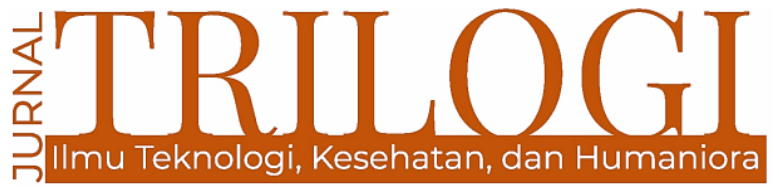

\title{
PENGARUH KUANTITAS KEGIATAN PESANTREN TERHADAP PRESTASI BELAJAR KEAGAMAAN SISWA MADRASAH ALIYAH NURUL JADID PAITON PROBOLINGGO
}

\author{
M Nafi Alisha \\ Sekolah Tinggi Agama Islam Istiqlal, Buleleng, Bali \\ nafi.alisha082@gmail.com
}

\begin{abstract}
This study aims to determine the impact of the quantity of Islamic boarding school activities on students' religious learning achievement at MA Nurul Jadid and the extent of the impact. The quantity of pesantren activity is a series of activities or can also be called the schedule of activities in the pesantren complex. Where the activity is highly correlated with the activities in the formal institutions in it, so that the combination of these activities can be a bridge to achieve achievements for some students. The method used in this study is a quantitative method. The sampling technique used in this study is Clauster Sampling, with a questionnaire instrument and documentation of several activities in the pesantren and the daily values of students as data collectors. The research population was 720 respondents from MA Nurul Jadid students, then $10 \%$ or 72 respondents were taken as samples. Analysis of the data using statistical techniques using the help of SPSS 16 Product moment with Interval data type. The results showed that there was no influence of the quantity of Islamic boarding school activities on student achievement at MA Nurul Jadid Paiton Probolinggo. In this case, it can be seen that the correlation coefficient is 0.056 with a significance of 0.643 . Because the significance is $>0.05$, then $\mathrm{H} 0$ is accepted, it means that $\mathrm{H} 1$ is rejected. if the results are consulted to the interpretation table of the value of $r$ (Product Moment) above, that the correlation is very low at $0.00-0.199$
\end{abstract}

Keyword: pesantren activities; learning achievement; Madrasah Aliyah Nurul Jadid 


\begin{abstract}
Abstrak
Penelitian ini bertujuan untuk mengetahui dampak kuantitas aktivitas pesantren terhadap prestasi belajar keagamaan siswa di MA Nurul Jadid serta sejauhmana kadar dampaknya. Kuantitas aktivitas pesantren merupakan rentetan beberapa kegiatan atau bisa disebut juga dengan jadwal kegiatan yang ada di kompleks pesantren. Di mana kegiatan sangat berkorelasi dengan kegiatan yang ada di lembaga formal yang ada di dalamnya, sehingga dengan adanya kombinasi kegiatan ini dapat menjadi jembatan untuk meraih prestasi bagi sebagian siswa. Metode yang digunakan dalam penelitian ini adalah metode kuantitatif. Teknik pengambilan sampel yang digunakan dalam penelitian ini adalah Clauster Sampling, dengan instrument kuesioner dan dokumentasi beberapa kegiatan yang ada di pesantren dan nilai-nilai harian siswa sebagai pengumpul datanya. Pupulasi penelitiannya sebanyak 720 responden yang berasal dari siswa MA Nurul Jadid, kemudian diambil sampelnya sebesar $10 \%$ atau 72 responden. Analisis datanya menggunakan teknik statistik dengan menggunakan bantuan SPSS 16 Product moment dengan jenis data Interval. Hasil penelitian menunjukkan bahwa tidak adanya pengaruh kuantitas aktivitas pesantren terhadap prestasi belajar siswa di MA Nurul Jadid Paiton Probolinggo Pada kasus ini terlihat bahwa koefisian korelasi adalah 0,056 dengan signifikansi 0,643. Karena signifikansi > 0,05, maka HO di terima, Berarti $\mathrm{H} 1$ di tolak . jika di hasil dikonsultasikan kepada table interpretasi nilai r (Product Moment) di atas, bahwa korelasinya sangat rendah berada pada angka 0,00 - 0,199.
\end{abstract}

Kata Kunci: aktivitas pesantren; prestasi belajar; Madrasah Aliyah Nurul Jadid

\section{Pendahuluan}

Secara etimologi kata pesantren berasal dari akar kata santri dengan awalan "pe"dan akhiran "an" berarti "tempat tinggal santri". Selain itu, asal kata pesantren terkadang dianggap gabungan dari kata "sant" (manusia baik) dengan suku kata "ira" (suka menolong), sehingga kata pesantren dapat berarti tempat pendidikan manusia baikbaik. (Samsul Nizar, 2013) Ziemek juga berpendapat bahwa secara bahasa, pesantren berasal dari suatu kata yaitu pe-santri-an, "tempat santri". Pesantren menjadi salah satu tempat belajar, baik belajar tentang ilmu pengetahuan umum lebih-lebih ilmu tentang pengetahuan agama. (Hariadi, 2015)

Sebagaimana diketahui bahwa santri yang ada di sebuah pesantren saat ini tidak hanya pindah rumah dan bertempat tinggal di pesantren, tetapi lebih dari itu, mereka belajar bersosial (bermasyarakat) disamping memperdalam pengetahuannya yang mencakup pengetahuan agama untuk bekal hidup di akhirat dan pengetahuan umum untuk bekal untuk dapat hidup dan berkiprah dalam kehidupan bermasyarakat, berbangsa dan bernegara. Dengan kondisi semacam ini, maka pesantren mau tidak mau akan terus berbenah dan menyesauaikan konteks kegiatannya dengan kebutuhan santri di masa depan, sehingga alumni pesantren akan tetap eksis dan mampu menyesuaikan diri dalam semua lini kehidupan.
Melihat kondisi pesantren saat ini, maka pesantren sudah menjadi tempat terfavorit bagi orang tua untuk mendidik putra-putrinya, sehingga santri yang datang ke pesantren berasal dari berbagai kota, budaya, adat, serta karakter yang berbeda-beda. Oleh karena itu beberapa faktor tersebut juga berpengaruh ke pondok pesantren dalam mencetak generasi yang berbeda-beda pula. Ada yang sukses dalam bidang akademik khususnya pengetahuan umum, ada yang sukses dalam bidang pengetahuan agama. Bagi seorang santri, pondok pesantren merupakan rumah kedua mereka di mana seorang santri lebih banyak mengahabiskan aktifitas mereka di pondok pesantren. Namun demikian kenyataan di lapangan menunjukkan bahwa sekalipun aktifitas yang dilakukan santri di sebuah pesantren bentuk dan kuantitasnya sama, tapi pada kenyataannya out put yang dihasilkan tidak sama.

Berdasarkan data kelembagaan, di Pondok pesantren Nurul Jadid terdapat sebuah lembaga pendidikan dengan nama Mdrasah Aliyah (MA) Nurul Jadid. Siswa atau siswi yang belajar di lembaga tersebut ditampung dan dibina dalam sebuah asrama khusus, ditempatkan dalam lingkungan dan wilayah yang sama, dalam aktivitas dan kepadatan aktifiyas yang sama. Tetapi pada kenyataannya, prestasi yang didapat masing-masing santri di lembaga tersebut berbeda-beda. Hal ini tentu menjadi sebuah fenomena yang sangat menarik untuk diselidiki. 
Berangkat dari hal tersebut, maka penelitian ini bertujuan untuk mengetahui : 1) Ada atau tidak adanya pengaruh kuantitas aktivitas pesantren terhadap prestasi belajar siswa di sekolah (MA Nurul Jadid); 2) Taraf atau besaran pengaruh kuantitas aktivitas pesantren terhadap prestasi belajar siswa di sekolah (MA Nurul Jadid).

\section{Kerangka Teori}

\subsection{Kajian tentang Kuantitas Aktivitas Pesantren}

Beberapa tokoh berbeda-beda dalam mendefinisikan aktivitas, namun mempunyai arah dan tujuan yang sama. Dalam kamus besar aktivitas berarti Aktivitas adalah keaktifan, kegiatan. (Tim Penyusun, 2003) Menurut Nasution, "aktivitas adalah keaktifan jasmani dan rohani dan kedua-keduanya harus dihubungkan". (S. Nasution, 2010) Menurut Zakiah Darajat, "aktivitas adalah melakukan sesuatu dibawa ke ranah perkembangan jasmani dan rohaninya". (Zakiah Darajat, 2011) Menurut Sriyono, "aktivitas ialah suatu kegiatan yang dilakukan baik secara jasmani atau rohani". Menurut Anton M. Mulyono, aktivitas artinya "kegiatan atau keaktifan". Jadi semua hal yang dilakukan atau kegiatan yang terjadi baik fisik maupun non-fisik, merupakan suatu aktifitas. (Nurhadiyanto, L. 2020)

Aktivitas jika dikaitkan dengan belajar, maka terdapat beberapa macam aktifitas yang diklasifikasikan oleh tokoh pendidikan, di antaranya: (S. Nasution, 2010)

1. Kegiatan-kegiatan visual, seperti membaca, melihat gambar-gambar, mengamati, eksperimen, demonstrasi, pameran, dan mengamati orang lain bekerja atau bermain;

2. Kegiatan-kegiatan lisan (oral), seperti mengemukakan suatu kenyataan atau prinsip, mengkorelasikan suatu kejadian, mengemukakan pertanyaan, memberi saran, mengemukakan opini, interview, diskusi dan interupsi;

3. Kegiatan-kegiatan mendengarkan, seperti mendengarkan percakapan, diskusi kelompok, mendengarkan radio, dll;

4. Kegiatan-kegiatan menulis, seperti menulis cerita, menulis laporan, memeriksa karangan, membuat rangkuman, mengerjakan tes, dan mengisi angket;
5. Kegiatan-kegiatan menggambar, seperti menggambar, membuat grafik, chart, diagram peta, dan pola;

6. Kegiatan-kegiatan metric, seperti melakukan percobaan, memilih alat, melaksanakan pameran, membuat model, menyelenggarakan permainan, menari dan berkebun;

7. Kegiatan-kegiatan mental, seperti merenung, serta mengingat, memecahkan masalah, menganalisis, melihat, hubungan-hubungan, dan membuat keputusan;

8. Kegiatan-kegiatan emosional, seperti minat, membedakan, berani, tenang.

Dari sekian aktifitas tersebut, pesantren menempatkan diri sebagai lembaga yang memiliki intensitas tinggi dalam membekali dan menyiapkan kader-kadernya dengan berbagai aktifitas yang berlangsung selama 24 jam agar para alumninya untuk dapat berkiprah secara maksimal saat mereka kembali lagi ke masyarakat. Agar aktifitas di pesantren berjalan dengan baik, maka dibentuklah beberapa devisi sesuai tugas pokok dan kewenangan masingmasing. Adapun devisi-devisi yang ada di Pondok Pesantren yang paling penting ialah sebagai berikut:

1. Devisi Ubudiyah (keagamaan). (BataBata.ac.id, 2020) Devisi ini bertugas mengkoordinir dan melakukan beberapa kegiatan sebagai berikut:
a. Sholat Tahajjud
b. Sholat Subuh Berjamaah
c. Sholat Duhur Berjamaah
d. Sholat Ashar Berjamaah
e. Sholat Maghrib Berjamaah
f. Sholat Isya' Berjamaah
g. Istighosah
h. Pembacaan Diba'iyah
i. Pembacaan Burdah
j. Puasa Sunnah

2. Devisi Pembinaan Al-Qur'an dan Furudhul 'Ainiyah. (Tim Penyusun, 2020) Devisi ini bertugas mengkoordinir dan melakukan beberapa kegiatan sebagai berikut:
a. Pembinaan Al-Qur'an bit Tajwid
b. Talqin 
c. Pembinaan Al-Qur'an malam hari dengan menggunakan metode sorogan

d. Pemberian materi dan praktek FA (Furudhul Ainiyah)

e. Khotmil Qur'an 2x seminggu

f. Sertifikasi Al-Qur'an

3. Devisi Kegiatan Belajar atau Study Club. (gontor.ac.id, 2020) Devisi ini bertugas mengkoordinir dan melakukan beberapa kegiatan sebagai berikut:
a. Muhadatsah Pagi
b. Belajar Pagi
c. Pengajian Kitab Pagi
d. Pengajian kitab kuning sore hari
e. Kegiatan belajar malam
f. Membaca doa sebelum belajar

Pada umumnya kegiatan sehari-hari seluruh pondok pesantren hampir sama, namun yang menjadi pembeda hanyalah waktu atau jam pelaksanaan. Jadi, kegiatan-kegiatan yang disebutkan di atas merupakan kegiatan umum dan yang pokok ada dalam pesantren.

Untuk itu, saat ini, banyak pesantren di Indonesia yang sudah membuka lembaga pendidikan umum, di samping pendidikan diniyah, untuk memberikan keleluasaan kepada masyarakat dalam berbagai bidang yang dibutuhkan bagi masa depan putraputrinya.

Sebagai tindak lanjut dari dibukanya lembaga pendidikan umum, pesantren juga memberi keleluasaan kepada setiap lembaga pendidikan di dalamnya untuk melakukan berbagai bentuk upaya dan berbagai bentuk aktifitas bagi pengembangan potensi anak didiknya. Berbagai upaya dan aktifitas ini sejalan dengan misi pesantren sebagai lembaga sosial dan sekaligus menjalankan fungsi pendidikan untuk pengkaderan penerus perjuangan ulama. Oleh karenanya tidak heran jika aktifitas keseharian santri yang tinggal di pesantren begitu padat dan bahkan bisa lebih padat dari kegiatan istirahatnya.

\subsection{Kajian tentang Prestasi Belajar}

Prestasi belajar sudah umum diartikan sebagai hasil dari kegiatan belajar yang dilakukan dengan penuh kesungguhan, baik berupa pengetahuan maupun keterampilan tertentu. Purwanto, prestasi belajar merupakan perolehan dari proses belajar siswa sesuai dengan tujuan pengajaran (ends are being attained). (Purwanto,
2009) Fathurrohman dan Sulistyorini, prestasi belajar adalah hasil yang telah dicapai dari suatu kegiatan yang berupa perubahan tingkah laku yang dialami oleh subyek belajar di dalam suatu interaksi dengan lingkungannya. (Faizatunni'mah Az Zulfa, 2014)

Namun demikian, prestasi belajar ini akan diketahui setelah dilakukan evaluasi belajar. Ada banyak jenis dan ragam penilaian prestasi belajar yang dilakukan oleh lembaga pendidikan, di antaranya:

1. Penilaian formatif adalah yang dilaksanakan pada akhir program belajar mengajar untuk melihat tingkat keberhasilan proses belajarmengajar itu sendiri.

2. Penilaian sumatif adalah penilaian yang dilaksanakan pada akhir unit program, yaitu akhir catur wulan, akhir semester, dan akhir tahun.

3. Penilaian diagnostik adalah penilaian yang bertujuan untuk melihat kelemahankelemahan siswa serta faktor penyebabnya.

4. Penilaian selektif adalah penilaian yang bertujuan untuk keperluan seleksi, misalnya ujian saringan masuk ke lembaga pendidikan tertentu.

5. Penilaian penempatan adalah penilaian yang ditujukan untuk mengetahui keterampilan prasyarat yang diperlukan bagi suatu program belajar dan penguasaan belajar seperti yang diprogramkan sebelum memulai kegiatan belajar untuk program ini.

Alat untuk mengukur prestasi belajar dapat menggunakan berbagai macam teknik penilaian sesuai dengan kompetensi dasar yang harus dikuasai. Dalam mengukur prestasi belajar harus menggunakan teknik. Ada dua teknik evaluasi, yaitu teknik nontes dan teknik tes. (Nana Sudjana, 2010)

1. Teknik Tes

Tes adalah pertanyaan-pertanyaan yang diberikan kepada siswa untuk mendapat jawaban dari siswa dalam bentuk lisan (tes lisan), dalam bentuk tulisan (tes tulisan), atau dalam bentuk perbuatan (tes tindakan). (Nana Sudjana, 2010) Ditinjau dari segi bentuknya untuk mengukur siswa, maka dibedakan atas adanya 3 macam tes, yaitu:

a. Tes tertulis

Tes tertulis ialah tes yang soal dan jawaban yang diberikan oleh siswa berupa 
bahasa tulisan. Contohnya seperti soal Pilihan Ganda, dan Essay

b. Tes lisan

Tes lisan adalah tes soal dan jawabannya menggunakan bahasa lisan. Contohnya guru melontarkan bebrapa pertanyaan lalu murid atau siswa langsung menjawab tanpa menulisnya di kertas akan tetapi dengan lisan atau suara.

c. Tes tindakan

Tes tindakan ialah tes dimana respon atau jawaban yang dituntut dari peserta didik berupa tindakan, tingkah laku kongkrit. Tes tindakan disini bisa disebut juga dengan Praktik. Misalnya pada mata pelajaran Fiqh materi tentang Thoharoh (macam-macam najis) perlu adanya praktik agar siswa paham baik dari segi materi dan cara mensucikannya.

2. Teknik Non Tes

Teknik non tes adalah penilaian atau evaluasi hasil belajar peserta didik, melainkan dilakukandengan tanpa menguji peserta didik. (Anas Sudijono, 2011) Adapun yang tergolong teknik non tes adalah

a. Skala bertingkat (rating scale)

Skala bertingkat adalah menggambarkan suatu nilai yang berbentuk angka terhadap suatu hasil pertimbangan.

b. Kuesioner (questionair)

Kuesioner adalah sebuah daftar pertanyaan yang harus diisi oleh orang yang akan diukur (responden).

c. Daftar cocok (check list)

Daftar cocok adalah deretan pernyataan (yang biasanya singkat-singkat) dimana responden yang ievaluasi tinggal membubuhkan tanda cocok $(\sqrt{ })$ ditempat yang sudah disediakan.

d. Wawancara (interview)

Wawancara merupakan suatu cara menghimpun berbagai bahan keterangan yang dilaksanakn dengan melakukan Tanya jawab lisan secara sepihak. Berhadapan muka dan dengan arah tujuan yang telah di tentukan.

e. Pengamatan (observation)

Pengamatan adalah cara untuk menghimpun bahan keterangan yang dilakukan dengan mengadakan pengamatan dan pencatatan secara sistematis terhadap fenomena-fenomena yang sedang di jadikan sasaran pengamatan.

f. Riwayat hidup

Riwayat hidup adalah gambaran tentang keadaan seseorang selama masa kehidupannya. (Suharsimi Arikunto, 2017)

\section{Metode}

Penelitian ini menggunakan pendekatan kuantitatif, dimana dalam penelitian ini banyak dituntut untuk menggunakan angka, mulai dari pengumpulan data, penafsiran data, penampilan data serta hasilnya. (H. Mansur, 1983) Oleh karena itu, rancangan penelitian ini dikembangkan selama proses penelitian berlangsung dan memperlakukan obyek penelitian, apa adanya. Pengambilan sampel dilakukan secara acak dengan prosentase sebesar $10 \%$ dari 720 siswa.

Kemudian untuk memperoleh data yang representative, teknik pengumpulan datanya menggunakan beberapa metode, yakni observasi, wawancara, dokumentasi dan angket.

Agar penelitian ini memperoleh hasil sesuai kaidah penelitian, maka terdapat 2 (dua) hipotesis yang diajukan dalam penelitian ini, yaitu 1) Hipotesis kerja $\left(\mathrm{H}_{1}\right)$ yang berbunyi : Ada pengaruh antara kuantitas aktivitas pesantren terhadap prestasi belajar siswa di sekolah (MA Nurul Jadid); dan 2) Hipotesis nihil $\left(\mathrm{H}_{0}\right)$ yang berbunyi : Tidak adanya pengaruh antara kuantitas aktivitas pesantren terhadap prestasi belajar siswa di sekolah (MA Nurul Jadid).

Teknik analisis data dalam penelitian ini menggunakan teknik analisis Product Moment dengan memanfaatkan bantuan aplikasi Statistical Package for the Social Science (SPSS) dan Microsoft Office Excel.

\section{Hasil Penelitian}

Sebagaimana telah disinggung di atas bahwa penelitian ini bertujuan mencari pengaruh kuantitas aktivitas pesantren terhadap prestasi belajar keagamaan siswa (studi kasus siswa MA Nurul Jadid) Paiton Probolinggo), maka berdasarkan hasil penelitian yang telah dilakukan, di MA Nurul Jadid didapat data sebagai berikut:

1. Pelaksanaan Kurikulum Asrama 
a. Kegiatan Kurikuler

Adalah kegiatan belajar mengajar yang dilakukan melalui tatap muka yang alokasi waktunya telah ditentukan dalam susunan program dan diperdalam melalui tugastugas. Kegiatan ini hanya terdapat dalam KBM. Dengan jadwal dan alokasi nwaktu yang telah ditentukan.

b. Kegiatan Ekstrakurikuler

Kegiatan eksta kurikuler merupakan kegiatan belajar yang dilakukan diluar sekolah untuk memperluas wawasan dan kemampuan. Peningkatan dan penerapan nilai dan kemampuan yang telah dipelajari dari berbagai mata pelajaran. Kegiatan ini meliputi kegiatan tutorial, remidial teaching, sorogan, kajian keagamaan dan kegiatan keorganisasian siswa

c. Kegiatan Tutorial

Program ini dimaksudkan untuk meningkatkan kemampuan siswa dalam bidang Agama Islam dan membekali siswa yang akan terjun ke masyarakat/masyarakat kerja. Program keterampilan agama ini dilaksanakan pada sore hari. Jumlah jam dan waktunya ditentukan sesuai dengan kebutuhan.

\section{d. Remidial Teaching}

Kegiatan ini dimaksudkan untuk memberikan tambahan pelajaran pada siswa yang kurang mengusai materi mata pelajaran yang dilaksanakan di asrama.

2. Kajian Ushul Fiqh

Kajian ini berorientasi untuk meningkatkan nalar siswa untuk mengetahuai asal-usul figh. Disamping itu juga kegiatan ini di maksudkan agar siswa mengetahui proses pembentukan hukum-hukum islam

3. Kajian Tafsir

Kajian ini untuk mengembangkan keilmuan siswa dibidang tata cara manafsirkan ayatayat yang ada dalam al-Qur'an dengan mengembangkan melalui metode-metode tafsir yang menjadi bahan diskusi.

4. Klasifikasi Kelas

Dalam pembelajaran siswa dikelompokkan menjadi tiga kelompok belajar (ula, wustho, dan ulya)

5. Ruang Lingkup Materi
Secara umum ruang lingkup materi meliputi pemahaman kitab klasik, bahasa asing (arab, inggris), dan Al-Qur'an dengan rincian:

a. Kitab
1) Ilmu-ilmu alat
2) Keterampilan baca
3) Kajian teks

b. Kebahasaan
1) Keterampilan kitabah/writing (menulis)
2) Keterampilan muhawarah/speaking (berbicara)

C. Al-Qur'an
1) IlmuTajwid
2) Gharoib al-ayah

6. Keorganisasian

Kegiatan ini merupakan kegiatan Asrama diluar kurikulum yang direncanakan oleh Asrama.Kegiatan ini ditujukan untuk mempersiapkan siswa agar mampu menjadi seorang pemimpin yang siap diterjunkan ke masyarakat. Kegiatan ini juga ditujukan sebagai proses pendewasaan siswa agar mampu bersikap dewasa.

Dalam keorganisasian ini ada beberapa organisasi yang ada di asrama MAK. Nurul jadid sebagai fasislitator siswa dalam menggodok kemampuan dan bakatnya:

a. Badan Eksekutif Siswa (BES)/Organisasi Siswi Intra Sakan (OSAKA).

Organisasi ini diibaratkan "pemerintah" yang merupakan organisasi siswa yang kegiatannya mengarah kepada pengembangan dibidang science dan skillsiswa yang meliputi keorganisasian, kebahasaan (Kitab/Bahasa Arab dan Bahasa Inggris).Semua mengacu kepada kompetisi dasar kurikulum asrama.

b. Badan Legeslatif Siswa (BLS)/Majlis Syuro Assakani (MSS)

Organisasi ini diibaratkan sebagai DPR/MPR yang mengontrol kegiatankegiatan yang telah direncanakan oleh BES/OSAKA.Serta membuat Garis-garis Besar Kegiatan Asrama (GBKA).

7. Pelaksanaan Kurikulum Sekolah 
Pelaksanaan kurikulum sekolah dilaksanakan melalui peminatan jurusan di Madrasah Aliyah Nurul Jadid.

\section{a. Peminatan IPA Unggulan}

Peminatan IPA unggulan yang lazim di MANJ disebut Unggulan IPA (UI) bertekad hadir sebagai bagian dari solusi bangsa yang menyiapkan kader dengan pemimpin bangsa di masa depan yang sarat dengan keunggulan IPTEK dan IMTAQ. Beberapa program yang dilaksanakan di Unggulan IPA sebagai berikut:

1) Meningkatkan kemampuan siswa dalam berkomunikasi secara aktif dengan menggunakan bahasa Inggris, baik di dalam maupun di luar kelas (asrama), maka pembelajaran dilaksanakan dengan beberapa macam:

1) Pembelajaran Bilingual menggunakan pengantar Bhs. Inggris untuk pelajaran matematika, fisika, kimia dan biologi

2) Test Toefl siswa kelas akhir bekerjasama dengan Universitas Negeri Malang

3) Kegiatan rutin di asrama untuk mengasah lifeskill seni dan kebahasaan seperti Monthly Discussion, English Debate, Audio Visual, MIC (MBI in Cinema), Morning Talk, Drama, Story Telling dll.

2) Meningkatkan kemampuan siswa dalam menggunakan ICT untuk efektifitas pembelajaran di dalam kelas.

a) Sarana pembelajaran berbasis ICT (Multimedia dan Internet) dan siswa didorong untuk mempunyai laptop

b) Ruang kelas dilengkapi dengan peralatan multimedia (Komputer, Internet, Audio Visual dan LCD Projector).

c) Pembuatan produk pembelajaran sains berbasis multimedia interaktif (flash, director, dreamweaver dII) seperti sains project.
3) Mengembangkan kurikulum bidang studi matematika dan sains dengan mengkombinasikan kurikulum nasional dan internasional:

a) Mengikuti test sertifikasi Cambridge mata pelajaran Matematika dan Biologi bekerjasama dengan SMA Darul Ulum Jombang.

b) Lomba Penelitian Sains seperrti Scientific Classroom Contest

c) Mendorong siswa dalam menerapkan keilmuan dan mempresentasinya dengan menggunakan Bhs. Inggris dalam kegiatan Science Project.

d) Pembinaan Olimpiade dan pendelegasian lomba-lomba.

4) Meningkatkan kepekaan sosial dan keorganisasian melalui Himpunan Siswa Peminatan unggulan IPA disebut ISO (Intelegent Student Organization)

5) Melaksanakan Travelling Study (Studi Wisata) bekerjasama dengan Laboratorium IPA Universitas Negeri Malang, ITS, PLTU, Kebun Raya Purwodadi Pasuruan, PT Sasa Inti Gending, PT. Otsuka Amarta Indah, dll.

6) Pembinaan intensif melalui tutorial di kelas dan asrama.

b. Peminatan Bahasa

Peminatan Bahasa (Programa Bahasa sebelumnya) yang secara struktural ada di bawah bagian kurikulum di Madrasah Aliyah Nurul Jadid adalah sebuah lembaga atau wadah bagi setiap siswa yang mempunyai minat, bakat dan kemampuan dalam bidang bahasa khususnya bahasa Arab, Inggris dan sastra Indonesia. Peminatan Bahasa MA. Nurul Jadid adalah lembaga yang memfokuskan pembinaan terhadap keterampilan bahasa bagi setiap peserta didiknya secara aktif dan pasif, baik keterampilan bahasa tulis ataupun lisan.Peminatan Bahasa merupakan suatu lembaga yang berperan penting dalam pelaksanaan pendidikan dan pengajaran bahasa Arab-Inggris dan sastra di MA. Nurul Jadid. Peminatan Bahasa ini terus berusaha meningkatkan mutu proses belajar mengajar dan kemampuan 
siswanya dengan senantiasa mengadakan perbaikan dan pembaharuan kurikulum pembelajaran dan sistem pengelolaan organisasinya.

Dalam rangka untuk meningkatkan kualitas kegiatan pendidikan dan pengajaran, Peminatan Bahasa memiliki berbagai kegiatan yang dapat dibedakan menjadi kegiatan harian, mingguan, bulanan, semesteran dan tahunan yang berorientasi pada life skill.Tidak hanya mengacu pada perencanaan yang telah ditetapkan, tetapi juga disertai kontrol, evaluasi serta penyesuaian terhadap perkembangan ilmu dan teknologi dewasa ini yang telah merambah pesat ke dalam sektor kehidupan masyarakat sehingga berjalan optimal dengan hasil yang diharapkan.

1) Program Harian :
a) Pendampingan Intensif
b) Bimbingan Ice Breaking
c) Penggunaan Bahasa Asing
d) Morning Talk/Short Speech
e) Penyampaian /Setoran Kosakata
f) Pembinaan Skill Club

2) Program Mingguan

a) Matrikulasi Bahasa Arab

Matrikulasi adalah kegiatan
belajar mengajar yang dikhususkan untuk pemula atau siswa baru yang duduk di kelas $X$ sebagai kelas persiapan dengan dibekali pengetahuan dasar tentang bahasa Arab dan untuk menyamaratakan kemampuan.

b) Matrikulasi Bahasa Inggris

Matrikulasi adalah kegiatan belajar mengajar yang dikhususkan untuk pemula atau siswa baru yang duduk di kelas $X$ sebagai kelas persiapan dengan dibekali pengetahuan dasar tentang bahasa Arab dan untuk menyamaratakan kemampuan.

c) Tutorial Bahasa Asing

d) Tutorial Bahasa Asing Asrama

e) Penerbitan Majalah Halaman
f) Percakapan Arab/Inggris
Berbahasa

3) Program Bulanan
a) Rapat Evaluasi Organisasi
b) Language Exhibition
c) Quiz/Talent School
d) Diskusi atau Kajian Ilmiyah
e) Audio Visual
f) Rapat Bulanan Pengurus Forsas
g) Seleksi Dan Training Peserta Didik Unggulan

4) Program Semesteran
a) Evaluasi Belajar Tutorial
b) Penerbitan Booklet

5) Program Tahunan
a) Rapat Kerja Organisasi (RAKER)
b) Pre-Tes Matrikulasi
c) Talk show bahasa asing
d) Training pengurus forsas
e) Diklat bahasa inggris
f) Diklat bahasa arab
g) Kompetisi Bahasa Asing Eksternal
h) Language's Creation
i) Language's Demonstration
j) Language's Got Talent
k) Lomba mengarang bahasa Asing
I) Room Stay in Learning/Teaching
m) Post-Tes Matrikulasi
n) Pendeligasian siswa ke Kompetisi OSIM
o) Kunjungan Belajar Siswa
p) Kompetisi Bahasa Asing Tingkat SLTP

6) Organisasi Siswa
a) Forum Siswa Bahasa Plus (Forsas)
b) Forum Siswi Bahasa Plus (Forsis)

\section{Peminatan IPS}

1) Mengadakan Kajian Ekonom Syariah 
Manfaat mempelajari kajian ini adalah agar siswa mengetahui dan paham tentang ekonomi yang sesuai dengan al-quran dan hadits sehingga tidak terjebak dalam riba serta mampu membandingkan ekonomi konvensional dengan ekonomi syariah, dan juga mengenal lebih mendalam bank dan lembaga keuangan syariah, di antaranya:
a) Bank Syariah seperti BMT, BSM, BNI Syariah, BRIS
b) Leasing Syariah
c) Koperasi Syariah
d) BUS ( Bnak Umum syariah )
e) UUS ( Unit Usaha syariah)

2) Mengadakan kajian sosial kemasyarakatan

Manfaat mempelajari kajian ini adalah agar siswa mengetahui dan paham tentang tingkah laku manusia, tertarik menganalisis berbagai jenis tingkah laku manusia, mampu mengendalikan diri dan bisa berbaur dengan masyarakat sekitar. Kajian ini meliputi:
a) Masyarakat pedalaman
b) Masyarakat pegunungan
c) Masyarakat pesisir
d) Masyarakat perkotaan
e) Masyarakat madrasah

3) Pendalaman penelitian berbasis riset Manfaat mempelajari penelitian berbasis riset adalah agar siswa mengerti dan faham tentang penelitian serta dapat menulis artikel ilmiah, makalah ilmiah dan karya tulis ilmiah, yang meliputi :
a) Ekonomi
b) Geografi
c) Sejarah
d) Sosiologi

4) Public speaking

Manfaat mempelajari public speaking adalah agar siswa terbiasa berbicara di masyarakat umum, memahami pentingnya komunikasi yang baik dan paham tentang ilmu komunikasi.
Ruang lingkup public speaking ini antara lain:
a) Masyarakat
b) Tokoh agama
c) Tokoh Masyarakat
d) Guru
e) Teman sejawat
f) Kakak tingkat

5) Menerbitkan buletin sosial, Ekonomi, Sejarah, Sosiologi dan Sastra

Manfaat kegiatan ini antara lain agar siswa terbiasa menulis, memahami pentingnya menulis dan memiliki pemahaman tentang ilmu jurnalistik

6) Seminar dan Praktikum Perbankan, Akutansi, Perpajakan, Pasar Modal dan Badan Peneyelenggara Jaminan Sosial

Manfaat kegiatan ini adalah agar siswa mengenal dan memahami dunia perbankan, memahami pentingnya pencatatan, mengenal dan bisa menghitung perpajakan, mengenal pentingnya pasar modal, mengenal dan memahami pentingnya BPJS. Ruang lingkung kegiatan ini antara lain:
a) Bank
b) Bendaharawan swasta dan negeri
c) $\mathrm{KP} 2 \mathrm{KP}$
d) $\mathrm{BEI}$
e) BPJS kesehatan dan ketenagakerjaan

\section{d. Peminatan IPA Unggulan}

1) Meningkatkan kemampuan siswa dalam berkomunikasi secara aktif dengan menggunakan bahasa Inggris, baik di dalam maupun di luar kelas (asrama)

2) Pembelajaran Bilingual menggunakan pengantar Bhs. Inggris untuk pelajaran matematika, fisika, kimia dan biologi

3) Test Toefl siswa kelas akhir bekerjasama dengan Universitas Negeri Malang 
4) Kegiatan rutin di asrama untuk mengasah lifeskill seni dan kebahasaan seperti Monthly Discussion, English Debate, Audio Visual, MIC (MBI in Cinema), Morning Talk, Drama, Story Telling dll.

5) Meningkatkan kemampuan siswa dalam menggunakan ICT untuk efektifitas pembelajaran di dalam kelas.

6) Sarana pembelajaran berbasis ICT (Multimedia dan Internet) dan siswa didorong untuk mempunyai laptop

7) Ruang kelas dilengkapi dengan peralatan multimedia (Komputer, Internet, Audio Visual dan LCD Projector).

8) Pembuatan produk pembelajaran sains berbasis multimedia interaktif (flash, director, dreamweaver dll) seperti sains project.

9) Mengembangkan kurikulum bidang studi matematika dan sains dengan mengkombinasikan kurikulum nasional dan internasional:

10) Mengikuti test sertifikasi Cambridge mata pelajaran Matematika dan Biologi bekerjasama dengan SMA Darul Ulum Jombang.

11) Lomba Penelitian Sains seperrti Scientific Classroom Contest

12) Mendorong siswa dalam menerapkan keilmuan dan mempresentasinya dengan menggunakan Bhs. Inggris dalam kegiatan Science Project.

13) Pembinaan Olimpiade dan pendelegasian lomba-lomba.

14) Meningkatkan kepekaan sosial dan keorganisasian melalui Himpunan Siswa Peminatan unggulan IPA disebut ISO (Intelegent Student Organization)

15) Melaksanakan Travelling Study (Studi Wisata) bekerjasama dengan Laboratorium IPA Universitas Negeri Malang, ITS, PLTU, Kebun Raya Purwodadi Pasuruan, PT Sasa Inti Gending, PT. Otsuka Amarta Indah, dII.

16) Pembinaan intensif melalui tutorial di kelas dan asrama

\section{Analisis Data}

Untuk mendapatkan nilai koefisien korelasi pada penelitian ini digunakan alat bantu berupa aplikasi SPSS.

Tabel 4.1

Correlations

\begin{tabular}{|l|l|l|l|}
\hline & & $\begin{array}{l}\text { Aktivitas } \\
\text { pesantren }\end{array}$ & $\begin{array}{l}\text { Prestasi } \\
\text { belajar }\end{array}$ \\
\hline $\begin{array}{l}\text { Aktivitas } \\
\text { pesantren }\end{array}$ & $\begin{array}{l}\text { Pearson } \\
\text { Correlation }\end{array}$ & 1 & 0.056 \\
\cline { 2 - 4 } & Sig. (2-tailed) & & 0.643 \\
\cline { 2 - 4 } & $\mathrm{N}$ & 71 & 71 \\
\hline \multirow{2}{*}{$\begin{array}{l}\text { Prestasi } \\
\text { belajar }\end{array}$} & $\begin{array}{l}\text { Pearson } \\
\text { Correlation }\end{array}$ & 0.056 & 1 \\
\cline { 2 - 4 } & Sig. (2-tailed) & 0.643 & 71 \\
\cline { 2 - 4 } & $\mathrm{N}$ & 71 & \\
\hline
\end{tabular}

Pada item $\mathrm{N}$ di kolom output di atas menunjukkan bahwa jumlah responden sebesar 71 orang sama halnya dengan jumlah responden yang mengisi angket aktivitas pesantren dan prestasi belajar.

Sedangkan item Sig. (2-tailed) menunjukkan nilai signifikansi dengan perolehan angka sebesar 0,643 . Jika nilai signifikansi tersebut dibandingkan dengan nilai kritik (critical value $=0,05$ ), maka nilai hitung signifikansi tersebut lebih kecil dari nilai kritik, yaitu 0,643>0,05 = tidak signifikan atau tidak ada pengaruh kuantitas aktivitas pesantren terhadap prestasi belajar siswa.

Untuk mengetahui besar pengaruh, dapat dilihat dari hasil nilai Peason Correlation atau analisis Pearson Product Moment dengan perolehan angka 0,056. Nilai r (Product Moment) tersebut lalu dikonsultasikan kepada table interpretasi nilai $r$ (Product Moment):

Tabel 4.2

Interprestasi nilai r.

\begin{tabular}{|c|l|}
\hline $\begin{array}{c}\text { Interval } \\
\text { Koefisien }\end{array}$ & \multicolumn{1}{|c|}{$\begin{array}{c}\text { Tingkat } \\
\text { Hubungan }\end{array}$} \\
\hline $0,00-0,199$ & Sangat Rendah \\
\hline $0,20-0,399$ & Rendah \\
\hline $0,40-0,599$ & Cukup \\
\hline $0,60-0,799$ & Kuat \\
\hline $0,80-1,000$ & Sangat Kuat \\
\hline
\end{tabular}

Dari hasil konsultasi kepada table interpretasi nilai $r$ (Product Moment) di atas, bahwa korelasinya sangat rendah berada pada angka $0,00-0,199$. 
Setelah diadakan analisis tentang perbedaan hasil rata-rata skor pre-test dan post-test masingmasing variable, maka dapat dijelaskan sebagai berikut:

1. Hipotesis kerja $\left(\mathrm{H}_{1}\right)$ yang berbunyi : Ada pengaruh antara kuantitas aktivitas pesantren terhadap prestasi belajar siswa di sekolah (MA Nurul Jadid).

2. Hipotesis nihil $\left(\mathrm{H}_{0}\right)$ yang berbunyi : Tidak adanya pengaruh antara kuantitas aktivitas pesantren terhadap prestasi belajar siswa di sekolah (MA Nurul Jadid).

Dari hasil output ke-2 (related Samples Sign Test) pada variable prestasi, didapat nilai Sig. (2tailed $)=0,643$ yang lebih besar dari 0,05 $(0,643$ $>0,05)$, sehingga dapat dikatakan $\mathrm{H}_{0}$ diterima dan $\mathrm{H}_{1}$ ditolak.

Berdasarkan hasil analisis tersebut, maka dapat disimpulkan bahwa tidak ada pengaruh kuantitas aktivitas pesantren terhadap prestasi belajar siswa di MA Nurul Jadid Paiton Probolinggo. Pengaruh kuantitas aktivitas pesantren dan prestasi belajar ditandai dengan sejumlah tanda yang menghasilkan tanda negative sebesar 72 . Ini berarti setelah diadakan penelitian tidaklah ada pengaruh kepadatan kegiatan di pesantren terhadap prestasi belajar siswa

\section{Penutup}

Kesimpulan yang dapat ditarik dari pembahasan penelitian dengan judul "Pengaruh Kuantitas Aktivitas Pesantren Terhadap Prestasi Belajar Siswa di MA Nurul Jadid" adalah 1) "Tidak ada pengaruh kuantitas aktivitas pesantren terhadap prestasi belajar siswa di MA Nurul Jadid". Hal ini dibuktikan dari korelasi pearson Sig. (2tailed) sebesar 0,643. Dimana nilai ini lebih kecil dari taraf signifikansi 0,005 yang diajukan. Jadi kuantitas aktivitas pesantren tidaklah berpengaruh terhadap prestasi belajar siswa. 2) Sedangkan besar pengaruh kuantitas aktivitas pesantren terhadap prestasi belajar siswa di MA Nurul Jadid Paiton Probolinggo adalah sangat rendah, yakni sebesar 0,056 dengan signifikasi 0,643 .

\section{Referensi}

Arikunto, Suharsimi. 2018. Dasar-Dasar Evaluasi Pendidikan. Jakarta: Bumi Aksara.

Az Zulfa, Faizatunni'mah. 2014. "Pengaruh Aktivitas Menghafal Al-Qur'an Terhadap prestasi belajar santri Bil-Ghaib", (Program Studi Ilmu Pendidikan Agama islam Fakultas Ilmu Tarbiyah dan Keguruan Institute Agama Islam Negeri Wali Songo Semarang)

Nurhadiyanto, Lucky. 2020. Analisis Cyber Bullying Dalam Perspektif Teori Aktivitas Rutin pada Pelajar Sma Di Wilayah Jakarta Selatan. IKRA-ITH HUMANIORA: Jurnal Sosial dan Humaniora, 4(2), 113-124.

Darajat, Zakiah. 2011. Metodik Khusus Pengajaran Agama Islam (Jakarta: Bumi Aksara)

Tim Penyusun. 2019. Buku Pedoman Santri Pondok Pesantren Nurul Jadid Paiton Probolinggo. Probolinggo: Pustaka Nurja.

Hariadi, 2015. Evolusi Pesantren, (Yogyakarta: PT LKIS Printing Cemerlang)

Mansur, 1983. Metodologi Penelitian Reserch, (Jakarta: PT Rineka Cipta)

Nasution, S. 2010. Didaktik Asas-Asas Mengajar (Jakarta: Bumi Aksara)

Nizar, Samsul. 2013. Sejarah Sosial \& Dinamika Intelektual Pendidikan Islam di Nusantara, (Jakarta: Kencana Prenada Media Group)

Purwanto, 2009. Evaluasi Hasil Belajar, (Yogyakarta: Pustaka Pelajar)

Sudijono, Anas. 2011. Pengantar Evaluasi Pendidikan, (Jakarta: Rajawali Press)

Sudjana, Nana. 2018. Penilaian Hasil Proses Belajar Mengajar, tp.

Tim Penyusun Kamus Pusat Bahasa, 2005. Kamus Besar Bahasa Indonesia, (Jakarta: Balai Pustaka)

https://www.Bata-Bata.ac.id/putri/pengasuhansantri/kegiatan-harian Di Akses pada tanggal 7 Maret 2020.

https://www.gontor.ac.id/putri2/pengasuhansantri/kegiatan-harian Di Akses Pada Tanggal 7 Maret 2020. 